\title{
Psychological Features of Verbal Communication of Employees of Preschool Education with Children from the Families of Participants of Anti-Terroristic Operations and Internally Transferred Persons
}

\section{Психолінгвістичні особливості вербальної комунікації працівників закладів дошкільної освіти з дітьми із сімей учасників антитерористичних операцій та внутрішньо переміщених осіб}

Iryna Lutsenko

Dr. in Pedagogy, Professor, Head of the Department of Methods and Technologies of Pre-school Education
Ірина Луценко

доктор педагогічних наук, професор, завідувач кафедри методик та технологій дошкільної освіти

E-mail: sofiras@ukr.net

orcid.org/0000-0001-8360-9943

National Pedagogical

University named after

M.P. Drahomanov

$\triangle 9$, Pirohov Str., Kyiv, Ukraine, 01601
Національний педагогічний університет імені М.П. Драгоманова

$\checkmark$ вул. Пирогова, 9, м. Київ, Україна, 01601

Original manuscript received March 27, 2018

Revised manuscript accepted September 15, 2018

\section{ABSTRACT}

The article is devoted to the problem of verbal communication of educators with children of preschool age from the families of participants of antiterroristic operations (ATO) and internally displaced people. The results of theoretical analysis of the problem of studying discourse as a psycholinguistic category are presented which, in the context of vocational-speaking activity, 
is considered as its verbalized, foreign-language phase. The interest of psycholinguistics in the study of the peculiarities of the discourse of the educational branch - pedagogical discourse is grounded since the latter is aimed at the realization of a wide range of functions (educational, communicative organizational, psychological (psychotherapeutic)), the basis of which is the implementation of the speech-impacting teacher by the addressee on their addressees (pupils). At the same time, discourse is highlighted as a dialogical process and reveals the two-sided nature of the influence of communicators on each other. Consideration of the teacher as the subject of the speech of the individual characteristics of the child-recipient, his mental condition is considered as a prerequisite for ensuring the intentional orientation of discourse. The emphasis is placed on the implementation of psychological (psychotherapeutic) functions by educators of preschool education, which is confirmed by the needs of the practice of education and development, verbal communication with children from the families of the participants of the ATO and the internally transferred people. The types of discourses aimed at providing emotional support to children of these categories in the form of discourses-positive partial assessments are defined and characterized, namely: discourse-agreement, discourse-encouragement, discourse-approval, discourseforward-looking positive assessment, as well as various kinds of discoursequestions. It is concluded that various discourses, in the course of which the speech influence on the child is carried out, its psychic state, feeling and behavior can be regarded as specialized discourse practice - a psycholinguistic phenomenon, the basis of which is the speech activity of its participants: educators of preschool education and children of preschool age.

Key words: discourse, dialogue discourse, discursive practice, speech effect, intentional orientation, sender, addressee.

\section{Вступ}

Різноманітність, різноплановість сучасного комунікативного середовища, складність міжособистісних, змістових процесів мовленнєвої комунікації, які в ньому відбуваються, викликали потребу вивчення й аналізу вербалізованої мовленнєвомислиннєвої діяльності іï учасників - дискурсу. На сьогоднішній день дискурс як лінгвістичний, психологічний, психолінгвістичний феномен описаний достатньо добре і проблематика досліджень підтверджує це. Коротко проаналізуємо їх. Так, завдяки поглядам Е. Бенвеніста закладено прагматичний аспект розуміння дискурсу; останній розглядається як висловлювання, яке породжується комунікантами 3 наміром адресанта впливати на свого співрозмовника 
Psychological Features of Verbal Communication of Employees...

(Бенвенист, 1974). Розуміння дискурсу як форми комунікації (чи «мови») вперше було введено Ю. Хабермасом (Хабермас, 1996). На погляд вченого лише в дискурсі можна отримати відповідь на запитання, що саме стоїть на заваді комунікативної взаємодії, спричиняє виникнення проблемних ситуацій. Як комунікативну подію визначає дискурс Т. ван Дейк, й підкреслює, що в ній задіяна не лише мова в іiі фактичному використанні, але й ментальні процеси, які супроводжують процес комунікації (Дейк ван, 1989). Як фундаментальні, ці погляди розвивалися наступними дослідниками дискурсу.

Дискурс - система комунікації, яка має реальний і віртуальний виміри, визначає О. Шейгал, й розкриває його як уявлення про типові моделі мовленнєвої поведінки, набір мовленнєвих дій та жанрів, специфічних для конкретного типу комунікації (Шейгал, 2000). Феномен мовленнєвого впливу, здійснюваного дискурсом у зв'язку з цільовою установкою мовця - суб'єкта мовленнєвого впливу, досліджує Іссерс (Иссерс, 2003), що узгоджується 3 тим, що вплив висловлювання на його одержувача має здійснюватися 3 урахуванням ситуації (Серио, 1999). Водночас у повсякденному спілкуванні мовленнєвий вплив може бути неусвідомленим (неінтенційним); у інституційному - інтенційною дією, спрямованою на адресата (Карасик, 2000). Проведені дослідження дозволяють зробити наступне узагальнення: дискурс створюється мовцем для слухача в певний час, у певному місці, 3 певною метою (Корольов, 2012).

Для нашого дослідження важливо 3'ясування того, що мовленнєвий вплив здійснює не тільки адресант. Урахування адресата і передбачення його відповідної реакції $є$ різнобічним, складним і напруженим процесом, результатом якого є зверненість, адресованість висловлювання (Бахтин, 1996: 200). Адресованість дискурсу розглядається обов'язковою вимогою при побудові персонального (індивідуально-орієнтованого) чи інституційного (статусно-орієнтованого) дискурсів (Карасик, 2000). На необхідності спільності мовної картини світу комунікаторів, двобічність процесів ii пізнання і осмислення комунікаторами вказують Т. Мілевська, К. Серажим (Милевская, 2002; Серажим, 2002).

Проведені дослідження дискурсу (Арутюнова, 1990; Кубрякова, 2000; Красных, 2012) створили наукове підгрунтя й наблизили 
Психолінгвістичні особливості вербальної комунікації працівників...

психолінгвістичне розуміння інтенціональної спрямованості дискурсу, підтвердили доцільність його вивчення як взаємодії двох індивідуальних свідомостей, способу вираження індивідуальної свідомості в комунікативній ситуації (Селиванова, 2004).

У низці досліджень дискурс тлумачиться як семіотичний процес, що реалізується в різних видах дискурсивних практик (Греймас, 1983). Поняття «дискурсивні практики» теоретично обгрунтовується (Деррида, 2000; Kristeva, 1981) та тлумачиться як змістово та формально близькі дискурси, об'єднані особливими правилами побудови, які охоплюють як мовленнєві, так i не мовленнєві дії. Дискурсивна практика визначається як типізований спосіб реалізації мовленнєвої діяльності, яка здійснюється відповідно до вимог певного типу дискурсу, що є загальноприйнятим у тій чи тій комунікативній сфері соціальної або професійної групи (Семенець, 2014).

3 огляду на те, що, будь яка галузь людської діяльності має власний, характерний для неї дискурс (Борботько, 2011), вчені досліджують дискурс за його тематичною і професійною спрямованістю: дискурс професій юриста, політолога, психолога, що привертає увагу дискурсивної психолінгвістики (Засєкіна, 2008) до вивчення особливостей дискурсу освітньої галузі педагогічного дискурсу.

Водночас в психолінгвістиці розвитку тема особливостей професійного дискурсу 3 дітьми дошкільного віку досліджена недостатньо, хоча й існують окремі дослідження, зокрема (Jose, 1988; Street \& Cappella, 1989; Filippova \& Astington, 2010; Перевалова, 2013). Проте вони не розкривають те, які типи дискурсів забезпечують найбільш ефективну вербальну комунікацію 3 дітьми, які пережили психотравмівні події.

Mema cmammi - представити результати психолінгвістичного дослідження вербальної комунікації вихователів закладів дошкільної освіти, як особливої дискурсивної практики 3 дітьми дошкільного віку 3 родин учасників АТО та внутрішньо переміщених осіб, визначити та обгрунтувати типи дискурсів, які забезпечують ефективне мовленнєве спілкування 3 такими дітьми.

\section{Методи та методика дослідження}

У дослідженні використано такі методи: теоретичні аналіз психологічної, лінгвістичної, психолінгвістичної літератури, 
Psychological Features of Verbal Communication of Employees...

узагальнення даних наукових досліджень, інтепретація законів спілкування, номінація i характеристика виділених дискурсів 3 урахуванням їх інтенційної і цільової спрямованості, висновування; емпіричні: цілеспрямоване спостереження за професійномовленнєвим спілкуванням вихователів 3 дітьми дошкільного віку, які пережили психотравмівні події, дискурс-аналіз практики вербальної комунікації вихователів ЗДО з дітьми дошкільного віку 3 родин учасників АТО і внутрішньо переміщених осіб; моделювання різних типів дискурсів для удосконалення вербальної комунікації вихователя з дітьми в реальній практиці роботи ЗДО.

\section{Результати дослідження та дискусії}

Вивчення та визначення психолінгвістичних особливостей дискурсів у дискурсивній практиці вихователів закладів дошкільної освіти було розпочато із з'ясування наявності в мовленні вихователів оптимальної сукупності різноманітних за спрямованістю мовленнєвих впливів, а саме: виховного, навчального, комунікативного, організаційного, розважального, психологічного (психотерапевтичного характеру), які продукуються ними в процесі організації життєдіяльності дитини в умовах закладу засобами професійно-мовленнєвого спілкування.

Необхідність виділення серед функцій-цілей професійномовленнєвого спілкування вихователя 3 дітьми дошкільного віку такої функції як надання дітям психологічної, зокрема психотерапевтичної допомоги (надається дітям, яким не потрібне спеціальне лікування) через здійснення дискурсивного впливу на їхню психоемоційну сферу з метою усунення в них негативних i збудження позитивних емоцій, підтверджується поглядами сучасних українських психологів і психолінгвістів (Бех, 2003; Кононко, 2003; Калмикова, 2010), а також потребами практики виховання i розвитку дітей 3 родин АТО i внутрішньо переміщених осіб. Коротко проаналізуємо їхні погляди.

Характеризуючи комунікативні стратегіï педагогічного спілкування, I. Бех виділяє стратегію «утішник», яка орієнтована компенсувати сили дитини, втрачені внаслідок образ, нерозуміння, неправильних дій, деструктивних взаємин. Вчений пропонує конструктивну дискурсивну технологію інтимно-особистісного діалогу в системі «вихователь - вихованці», підкреслюючи, що 
реалізація дискурсу залежить від ставлення вихователя до дитини і професійності його комунікативних дій (Бех, 2003). Необхідність здійснення впливу, зокрема реалізації педагогом закладу дошкільної освіти функції психотерапевта підкреслює О. Кононко (Коментар до Базового компонента, 2003). На потребу у психологічній допомозі дітям з метою забезпечення їхнього психічного здоров'я, усунення труднощів спілкування вказує Л. Калмикова (Калмикова, 2016), й зазначає, що нині психотерапевтичні форми, методи i засоби впливу $\epsilon$ складовою сучасних психолінгвотерапевтичних технологій, що використовуються у роботі 3 дітьми дошкільного віку (Калмикова, 2016).

3 метою виявлення особливостей вербальної комунікації вихователів 3 дітьми 3 родин учасників АТО i внутрішньо переміщених осіб спочатку були з'ясовані психологічні особливості цих дітей та психолінгвістичні особливості їхніх висловлювань, які описані у роботі (Луценко, 2018), а також здійснено інтерпретацію комунікативних законів спілкування, сформульованих I. Стерніним (Стернин, 2001). Ці закони спілкування, за умови ïx інтерпретації 3 психолінгвістичних позицій, $\epsilon$ інтегрованими психолінгво-комунікативними параметрами, які нарівні $з$ психологопедагогічними вимогами, визначають особливості дискурсивних практик вихователів ЗДО. Отже, розглянемо ті закони які, на наш погляд, найбільш пов'язані з ситуаціями професійно-мовленнєвого спілкування вихователів. Це закони:

- дзеркального розвитку спілкування, згідно з яким його учасники імітують одне одного. Педагог ураховує дію цього закону для нейтралізації негативних способів вербальної комунікації вихованців й продукує у своєму мовленні, наприклад, дискурсввічливу згоду, дискурс-ввічливу відмову, а діти-комунікатори наслідують ці дискурси у сфері вербальної комунікації з однолітками та дорослими;

- закон залежності ефективності спілкування від комунікативних зусиль його учасників. Педагог приділяє належну увагу всім фазам породження мовлення як у власних висловлюваннях, так і у мовленнєвій діяльності дітей. Постійний самоконтроль дозволяє комунікатору уникнути неінтенційних, без урахування цілі, спрямованості, наслідків впливу педагогічного дискурсу на комунікантів; 
Psychological Features of Verbal Communication of Employees...

- закон ритму спілкування. При використанні організованих форм, спрямованих на розвиток мовленнєвої діяльності дітей та в процесі повсякденної вербальної комунікації педагог забезпечує доцільне співвідношення між говорінням, коли він виступає у ролі мовця, адресанта - суб’єкта мовлення, і слуханням (педагог виступає у ролі адресата дитячих висловлювань): він створює мовленнєві ситуації, у яких діти-комуніканти в змозі «набрати» потрібний для говоріння обсяг (реалізація ними ролі адресанта мовлення) для задоволення природної дитячої потреби у мовленнєвому спілкуванні; також з цією метою педагог сприяє самостійним видам мовленнєвої діяльності дітей, де вони комунікують між собою й у ролі адресатів і адресантів мовлення виступають їхні однолітки;

- закон мовленнєвого самовпливу. Відповідно до цього закону педагог, враховуючи його дію, в процесі діалогічного дискурсу спонукає дитину до монологічного мовлення, сприяє виникненню у неї мовленнєвих мотивів, утворенню мовленнєвих інтенцій і у такий спосіб спрямовує дитяче висловлювання, допомагає ій як суб'єкту мовлення виразити свій емоційний стан, передати через мовні засоби враження, сумніви, хвилювання, страхи, думки, що турбують. Завдяки вербальній комунікації, вербальному позначенню свого стану, травмівної ситуації, в якій вона перебуває, дитина краще осмислює їх, однак їі самовплив на власний психоемоційний стан залишається ненаміреним, неусвідомленим;

- закон довіри до зрозумілих висловлювань. Педагог ураховує наступні вимоги до мовленнєвої комунікації, а саме: висловлювання згідно з Г. Грайсом має: а) містити стільки інформації, скільки iii потрібно для досягнення поточних цілей комунікації; б) бути правдивим; в) бути релевантним - відповідати предмету розмови; в) бути зрозумілим, описані (Грайс, 1985) - й створює для дітейадресатів доступні за обсягом, предметною спрямованістю, змістом, i мовним оформленням дискурси; мовленнєво-компетентний педагог, здатний викликати в процесі вербальної комунікації довіру дітей та привернути увагу до себе як до мовця, є бажаним для дітей-комунікаторів адресантом; створені ним дискурси досягають спланованої цілі дискурсивного впливу;

- закон притягування критики. Педагог не виносить на обговорення зі сторонніми дорослими та вихователями проблеми тих дітей, які виділяються 3-поміж інших своєю комунікативною 
поведінкою, що зумовлена стрес-факторами, конфліктною вербальною комунікацією з дорослими і однолітками, мовленнєвими труднощами, що детерміновані психотравмівними подіями, й які можуть загострюватися через нерозуміння вихователем наслідків перенесення дітьми психотравми; педагог висловлюється про цих дітей позитивно й адресує їм позитивні емоційно забарвлені або нейтральні (не засудливі) дискурси;

- закон модифікаиії нестандартної комунікативної поведінки учасників спілкування. Педагог адресує дитині, у комунікативній поведінці якої мають місце відхилення, індивідуально-орієнтовані дискурси, створені з метою здійснення мовленнєвих впливів на соціально-комунікативну сферу, стабілізації психоемоційного стану і мовленнєвого розвитку дитини; для досягнення позитивних змін доцільними можуть бути такі дискурси: дискурс-спонука, дискурснаснага (Калмиков, 2018), психолінгвотерапевтичні технології (арт-терапія, музикотерапія, казкотерапія);

- закон емоиійної афіліаиіï («зараження») особи. Педагогадресант цілеспрямовано продукує підбадьорювальні, радісні, оптимістичні дискурси та 3 їх допомогою створює і підтримує психологічно комфортну, підкріплену позитивними емоціями комунікативну атмосферу; 3 метою виникнення у дитини, яка перебуває у негативному психоемоційному стані, позитивнозафарбованих емоцій педагог здійснює у формі дискурспозитивної установки індивідуально орієнтовані психотерапевтичні мовленнєві впливи;

- закон мовленнєвого посилення емоції. Враховуючи дію закону, педагог на фазі лексико-граматичного структурування продукованого дискурсу добирає емоційно забарвлену лексику, здатну збуджувати позитивні почуття, радісні емоції, впливати на настрій дітей. Він також вербалізує позитивні оцінки, позначає радісні емоції, почуття, стани і таким чином посилює їх й уникає зайвого вербального позначення негативних оцінок, емоцій, почуттів, станів;

- закон мовленнєвого поглинання емоиії. Для врахування в роботі дії цього закону педагог змістом й ходом діалогічного дискурсу допомагає дитині «зустрітися» зі своєю негативною емоцією та вербалізувати іiі, виразити у мовленні те, що іiі турбує, висловитися про свої переживання, страхи i завдяки такому 
Psychological Features of Verbal Communication of Employees...

проговорюванню значно зменшити силу небажаної емоції. Часто діти інтуїтивно вдаються до такого способу полегшення процесу переживання негативної емоції й ii послаблення, а педагог вербально підтримує їхнє мовленнєве самовираження.

3 метою надання дітям 3 родин учасників АТО та внутрішньо переміщених осіб, які пережили психотравмівні події, своєчасної педагогічної підтримки і психологічної допомоги, спрямованої на врівноваження їхньої психіки, доцільною $є$ міжособистісна емоційно підтримуюча вербальна комунікація, яка пронизує усі процеси життєдіяльності дітей. Для іiі реального конституювання перелік традиційних функцій-цілей професійно-мовленнєвого спілкування, представлений в (Луценко, 2009) розширимо такими новими функціями-цілями, як: досягнення емоційно-ціннісної єдності вихователя 3 дітьми; відновлення втраченої психологічної рівноваги дітей, iї збереження; встановлення емоційної довіри й підтримка позитивної атмосфери спілкування; пом'якшення, зняття, компенсування засобами педагогічного мовленнєвого впливу емоційного напруження, травмівної дії на дітей стресогенних чинників.

Введення такої дискурсивної функції-цілі, як досягнення емоційно-ціннісної спільності вихователя 3 дітьми, обгрунтовуємо твердженням В. Мясищева (Мясищев, 1960) про те, що сприйнятливість до мовленнєвого впливу є результатом динамічних взаємостосунків людей. Отже, успішний дискурсивний вплив залежить від довіри і любові дитини-адресата до особистості педагога-адресанта; між ними має бути взаємний інтерес, позитивне ставлення, емоційна близькість (довіра, прихильність), наявність спільного на рівні переживань, схильностей, дій, досвіду, цінностей, ставлень. Щоб взаємодіяти 3 дитиною на засадах емоційної близькості, щирої зацікавленості педагог-адресант має бути чутливий до зворотних впливів дітей-адресатів. Під дискурсивними впливами розуміємо вербально виражені у формі мовленнєвих реакцій i активних, ініціативних мовленнєвих дій стани, переживання, почуття, уявлення, думки дітей.

Оскільки можливим наслідком дії на психіку дитини психотравмівних ситуацій є посттравматичний стрес, що здійснює гальмівний вплив на різні сфери психічного розвитку, зокрема: емоційну, комунікативну, когнітивну та ін., постільки суттєво 
знижуються активні, ініціативні мовленнєві прояви дітей. Тому 3 метою відновлення їхньої мовленнєвої активності і надання їм емоційної підтримки на етапі виконання мовленнєвих дій необхідні різноманітні дискурси. 3 метою їх вивчення й виокремлення, та виділення серед них найбільш ефективних, нами було проведено спостереження за вербальною комунікацією вихователів закладів дошкільної освіти дітьми з родин учасників АТО і внутрішньо переміщених осіб. Відбувалася фіксація використаних педагогами дискурсів. Проведений дискурс-аналіз висловлювань вихователів дозволив виокремити такі дискурси як: дискурси-позитивні париіальні оцінки або дискурси-підтримки. Серед важливих компонентів цього типу індивідуально адресованого дискурсу було виділене індивідуальне звертання до кожної дитини на іiі ім'я у пестливій формі, яке своїм змістом емоційно підтримує, втішає й мотивує дитину. Розглянемо види дискурсів, які відносимо до дискурс-підтримки:

Дискурс-згода сприяє впевненості дитини у правильності власних дій, стимулює до подальшої мовленнєвої діяльності, підтримує іiі. Дискурс-згоді притаманна така лексика: «так», «правильно», «згодна з тобою» або повторення доцільних висловлювань дитини, якщо вона виявляє мовленнєву монологічну активність. Проте вплив цього виду дискурсу на афективно-вольову сферу дошкільника не достатній. Доречнішими $\epsilon$ дискурси, в яких наявні забарвлені слова й фрази як: «дуже добре», «вдало», «цікаво», «як гарно ти сказав», «щораз в тебе виходить краще».

Дискурс-підбадьорювання передбачає емоційну підтримку дитини. Особливо іiі потребують діти замкнені, нерішучі, невпевнені у своїх силах, які переживають негативні психоемоційні стани. Цей вид дискурсу спрямований на відзначення найменших успіхів дитини. Наприклад: «Миколко, як гарно ти почав свою розповідь. A тепер продовж ї̈»; «Петрику, ти став такий самостійний. Сам розпочав, а тепер заверши свій малюнок». Продукуючи різні варіанти дискурсів-підбадьорювань, вихователь обгрунтовує, в чому саме полягає успіх, досягнення дитини, також він привертає увагу інших дітей до іiі відповіді чи дій: «Зверніть увагу, діти, як Данилко вдало добирає слова й иүікаво розповідає - описав як ввечері стомлене сонечко заходить за обрій». 
Psychological Features of Verbal Communication of Employees...

Дискурс-схвалення зорієнтований на особистість дитини. У схваленні звертається увага не тільки на іiі конкретний успіх; головне - позитивно оцінюється особистість дитини вцілому, висловлюється доброзичливе, емоційно-ціннісне ставлення до малюка: "Оленко, ти наче сонечко, твоя привітність радує усіх», «Віталику, ти - хороший хлопчик $i$ гарний товариш, $i$ y тебе з'явилися нові друзі», «Молодецьь, Юрко! Так добре, щзо ти навчився поступатися і твоїм друзям приємно з тобою гратися», "Я радію, Марійко, за тебе, ти така розумниияя!».

Дискурс-позитивна випереджальна оцінка спрямовує дитину на успіх у діяльності та позитивні зміни у її станах, діях, поведінці; спонукає дітей до практичних дій, вербальної комунікації 3 однолітками: «Назарчику, зараз ти сам запросиш дітей гратися 3 тобою. У тебе вийде добре. Ось, запроси Віталика погратися 3 тобою, запропонуй йому бути водієм вантажівки. Він буде радий».

Як засвідчили спостереження, індивідуалізація вербальної комунікації вихователів 3 дітьми 3 родин учасників ATO та внутрішньо переміщених осіб залежить від типу й рівня розвитку дітей: гармонійний високий, гармонійний середній чи дисгармонійний рівень активності мовленнєвого спілкування. Тому вихователі використовували дискурси-запитання, які відрізнялися різним ступенем навіювання. Наведемо їх приклади:

- Запитання, які не містять сугестивного впливу, створюють передумови для виявлення дитячої ініціативи під час вибору теми, змісту й спрямування ходу розмови: «Тетянко, про щзо ти хотіла мені розповісти?», «Мишко, про щзо ще ти хотів поговорити?». Такі дискурси-запитання адресуються дітям упевненим, комунікабельним, із гармонійно високим рівнем розвитку, а також дітям, яким треба створити умови, щоб вони змогли виговоритися, задовольнити свою потребу у мовленнєвому спілкуванні чи висловитися про те, що їх турбує.

- Запитання, які передбачають альтернативний вибір, дають змогу вихователю управляти вербальною комунікацією, але при цьому дитина дістає можливість вибрати зміст розмови, спрямувати за бажанням подальший iіi хід, вибрати 3 наведених варіантів правильний чи бажаний: «Наталочко, про щзо ти хотіла мені розповісти: про маленьку сестричку чи про свої справи?», «Сергійку, ти зрозумів, як можна помиритися з товаришем, чи ще 
поговоримо про цее?». Такі дискурси-запитання адресувалися дітям, яким важко вступити у мовленнєвий контакт, почати розмову через власну невпевненість або недовіру до співрозмовника, вихованцям із гармонійно середнім рівнем розвитку.

- Запитання, які містять непряме навіювання відповіді, спрямовують дитину на правильну відповідь, варіант виходу 3 певної ситуації: «Павлусь, пригадай, які слова допомагають нам бути ввічливими співрозмовниками. То які слова треба сказати, щуоб діти на тебе не ображалися?», «Наталочко, як треба звернутися до дітей, якщуо хочеш, щуоб вони прийняли тебе у гру, чи поділилися іграшкою?», «Миколко, щуо сказав тобі під час розмови по телефону татусь про твою поведінку, якою вона має бути?». Такі дискурси - запитання адресувалися дітям із дисгармонійно суперечливим рівнем розвитку та труднощами мовленнєвого спілкування 3 однолітками й адаптації до нових соціальних умов.

- Запитання - активне навіювання відповіді: «Сашко, ти хвилюєшся, бо скоро зустрінешся зі своїм батьком?», "Христинко, ти пригадуєш про щзо ми з тобою домовилися? Розмовляти про те, за ким чи чим ти сумуєи». Запитання такого типу використовують у ситуаціях, які потребують прямого впливу, втручання у внутрішній світ дитини, вербальної комунікації з дітьми із низьким рівнем розвитку.

В процесі діалогічного дискурсу 3 метою встановлення емоційного контакту 3 дітьми та його підтримання вихователі використовують лексико-граматичні засоби діалогізації мовлення. Їх ряд доцільно доповнити такими: «я вважаю», «здається», «на жаль», «як добре!», «от шкода!», «ціккаво»; для демонстрації особистісного (емоційного) ставлення до предмета розмови добиралися вислови: «Мені сподобалося...», «Мені стало сумно... », "Я зраділа...», "Мені цікаво дізнатися про...», "Я здивувалася...».

Отже, у процесі вербальної комунікації з дітьми дошкільного віку 3 родин учасників АТО i внутрішньо переміщених осіб вихователі продукують дискурси відповідно до індивідуально визначеної цілі мовленнєвого впливу на особистісну чи психічну сферу розвитку дитини в конкретній мовленнєвій ситуації. Такі дискурси створюються на психолінгвістичних засадах творення висловлювання 3 вираженою інтенціональною спрямованістю, 
Psychological Features of Verbal Communication of Employees...

зрозумілим дітям змістом, чіткою структурою, доречним мовним оформленням.

Різноманітність мовленнєвих впливів, які здійснює вихователь, a саме: комунікативний, психотерапевтичний, виховний та ін., визначає необхідність використання широкого спектру типів i видів педагогічного дискурсу. Ці дискурси об’єднують спільні психолінгво-комунікативні параметри та психолого-педагогічні вимоги до вербальної комунікації вихователя ЗДО 3 дітьми дошкільного віку. Це дало змогу класифікувати їх як особливий вид дискурсивної практики.

\section{Висновки}

Психолінгвістичне обгрунтування вербальної комунікації вихователів 3 дітьми дошкільного віку 3 родин учасників АТО i внутрішньо переміщених осіб стало можливим у зв'язку 3 розширенням предмета вітчизняної психолінгвістики, охопленням сучасною наукою широкого спектру проблем, пов'язаних як із психічними механізмами утворення мовлення, так і з соціальною взаємодією, комунікацією. Розвиваючись в межах психологічної теорії діяльності, сучасна діяльнісна психолінгвістика є підгрунтям для дослідженням проблем професійно-мовленнєвої діяльності. Вона вивчає аспекти вербальної комунікації вихователів ЗДО, у процесі якої мовленнєвий вплив на особистість дитини, їі поведінку, почуття, психоемоційний стан здійснюється у формі спеціалізованої дискурсивної практики - психолінгвістичного феномену, в основі якої лежить мовленнєва діяльність ï учасників: вихователів ЗДО і дітей дошкільного віку.

Дискурсивну практику вихователів 3 дітьми 3 родин учасників ATO i внутрішньо переміщених осіб, які пережили психотравмівні події, характеризує спрямованість на психологічну (психотерапевтичну) корекцію психоемоційних станів дітей, їхню емоційну підтримку. 3 цією метою використовуються такі види педагогічних дискурсів, як дискурс-згода, дискурс-підбадьорювання, дискурс-схвалення, дискурс-випереджальна оцінка, які $\epsilon$ певними аналогами дискурсів-підтримки, які застосовуються у психологічному (психотерапевтичному) дискурсі.

Перспективу подальших досліджень вбачаємо у подальшому вивченні дискурсів, спрямованих на вирішення проблемних ситуацій 
Психолінгвістичні особливості вербальної комунікації працівників...

комунікативно-мовленнєвої взаємодії з дітьми дошкільного віку, які пережили психотравмівні події.

\section{Література}

Арутюнова, Н.Д. Дискурс. Лингвистический энциклопедический словарь. Режим доступу: http://tapemark.narod.ru/les/136g.html

Бахтин, М.М. Проблема речевых жанров. Собрание сочинений: $87 \mathrm{~m}$. Москва : Русские словари, 1996. Т. 5. С. 159-206. Режим доступу: http:// philologos.narod.ru/bakhtin/bakh genre.htm

Бенвенист, Э. Общая лингвистика / Под ред. Ю.С. Степанова. Москва : Прогресс, 1974. $446 \mathrm{c}$.

Бех, І.Д. Виховання особистості : у 2-х т. Київ : «Либідь», 2003. Т. 2. 342 с.

Борботько, В.Г. Принципы формирования дискурса: От психолингвистики к лингвосинергетике. 4-е изд-е. Москва : Либроком, 2011. 288 с.

Деррида, Ж. О грамматологии. Москва : Ad Marginem, 2000. 512 с.

Дейк ван, Т.А. Язык. Познание. Коммуникация : Пер. с англ. / Сост. В.В. Петрова ; Под ред. В.И. Герасимова ; Вступ. ст. Ю.Н. Караулова и В.В. Петрова. Москва : Прогресс, 1989, 312 с.

Грайс, Г.П. Логика и речевое общение. Новое в зарубежной лингвистике. Москва : Прогрес, 1985. Вып. XVI. C. 217-237.

Греймас, А. Семиотика. Объяснительный словарь теории языка. Москва : Радуга, 1983. C. 483-550.

Засєкіна, Л.В. Тенденції розвитку вітчизняної психолінгвістики: методологічний огляд проблем та окреслення шляхів їх вирішення. Психолінгвістика. 2008. Вип. 1. Режим доступу: http://nbuv.gov.ua/UJRN/psling 2008 1 2.

Иссерс, О.С. Коммуникативные стратегии и тактики русской речи. Москва : Эдиториал УРСС, 2003. 284 с.

Калмиков, Г.В. Тенденції розвитку психологічної теорії діяльності як світоглядної позиції діяльнісної психолінгвістики. Психолінгвістика. 2012. Вип. 10. C. 41-49.

Калмиков, Г.В. Психолого-професійний дискурс як вираження інтенціональної спрямованості суб'єкта мовлення на адресата. Psycholinguistics. Психолінгвістика. Психолингвистика. 2018. Вип. 23(1). С. 73-98. doi: 10.5281/zenodo. 1212362

Калмикова, Л.О. Формування у дітей старшого дошкільного віку мовленнєвої діяльності : діагностико-розвивальний комплекс. Київ : Видавничий Дім «Слово», 2016. 384 с.

Коментар до Базового компонента дошкільної освіти в Україні. Київ : Ред. журн. «Дошкільне виховання», 2003. 243 с.

Карасик, В.И. О типах дискурса. Языковая личность: институциональныий и персональный дискурс. 2000. С. 5-20.

Корольов, І.Р. Поняття дискурсу в сучасному мовознавстві: визначення, структура, типологія. Лінгвістика. 2012. Вип. 6. С. 285-305.

Красных, В.В. Основы психолингвистики. Москва : Гнозис. 2012. 333 с.

Кубрякова, Е.С. О понятиях дискурса и дискурсивного анализа в современной лингвистике. Дискурс, речь, речевая деятельность: функииональные и структурные аспекты: сб. обзоров РАН ИНИОН. Москва, 2000. С. 7-25. 
Psychological Features of Verbal Communication of Employees...

Луценко, І.О. Теоретичні та методичні засади розвитку комунікативно-мовленнєвої сфери дитини від народження до 6 років: [монографія]. Київ : Вид-во НПУ імені М.П. Драгоманова, 2009. 291 с.

Луценко, І.О. Дитиноцентризм як методологічний концепт виховання і розвитку дітей дошкільного віку з родин учасників АТО і внутрішньо переміщених осіб. Пост-травматичний стресовий розлад: дорослі, діти та родини в ситуації війни. 2018. Том III. Варшава-Київ. ПАН-Гнозис. С. 313-321.

Милевская, Т.В. О понятии «дискурс» в русле коммуникативного подхода. Материалы Международной научно-практической конференции «Коммуникация : теория и практика в различных социальных контекстах «Коммуникация-2002» («Communication Across Differences»). Пятигорск : ПГЛУ, 2002. Ч. 1. С. 188-190.

Мясищев, В.Н. Основные проблемы и современное состояние психологии отношений человека. Психологические науки в СССР. Москва, 1960. Т. 2.

Перевалова, Д.А. Педагогический дискурс: дискурс дошкольного образования. Вестник Томского государственного университета. 2013. № 368. С. 23-26. Режим доступу: https:cyberleninka.ru/article/v/pedagogicheskiy-diskurs-diskursdoshkolnogo-obrazovaniy

Семенець, О.О. (2014). Дискурсивні практики соціальних комунікацій: творчість суб'єкта мовлення та механізми самоорганізації. Режим доступу: http:/elib. bsu.by/bitstream/123456789/106190/1/Semenec.PDF

Серажим, К. Дискурс як соціолінгвальне явище: методологія, архітектоніка, варіативність : [монографія]. Київ, 2002. 392 с.

Серио, П. Как читают тексты во Франции. Вступительная статья. Квадратура смысла: Франиузская икола анализа дискурса. Москва : ОАО ИГ «Прогресс», 1999. С. 12-53.

Селиванова, Е.А. Основы лингвистической теории текста и коммуникации. Київ : Брама, 2004. 336 с.

Стернин, И.А. Введение в речевое воздействие. Воронеж : Полиграф, 2001. 252 с.

Хабермас, Ю. Комунікативна дія і дискурс - дві форми повсякденної комунікації. Першоджерела комунікативної філософії. Київ : Либідь, 1996. С. 84-90.

Шейгал, Е.И. Семиотика политического дискурса. Москва : Волгоград: Перемена, 2000. $368 \mathrm{c}$.

Kristeva, J. (1981). Le language, cet inconnu. Paris : Ed. du Seuil.

Street, R.L., \& Cappella, J.N. (1989). Social and linguistic factor influencing adaptation in children's speech. Journal of Psycholinguistic Research, 18(5), 497-519. doi: 10.1007/BF01067313

Jose, Paul E. (1988). Sequentiality of Speech Acts in Conversational Structure. Journal of Psycholinguistic Research, 17(1), 65-88. doi: 10.1007/BF01067181

Filippova, E., \& Astington, J.W. (2010). Children's Understanding of Social-Cognitive and Social-Communicative Aspects of Discourse Irony. Child Development, 81(3), 913-928. URL: https://www.jstor.org/stable/40599142

\section{References}

Arutyunova, N.D. Diskurs. Lingvisticheskij ehnciklopedicheskij slovar [Discourse. Linguistic Encyclopedic Dictionary. Access mode]. URL : http://tapemark.narod. $\mathrm{ru} / \mathrm{les} / 136 \mathrm{~g} . \mathrm{html}$ 
Психолінгвістичні особливості вербальної комунікації працівників...

Bakhtin, M.M. (1996). Problema rechevykh zhanrov [The problem of speech genres]. Sobranie sochinenij - Collected works (Vols. 1-7) (Vol. 5), (pp. 159-206.). Moscow [in Russian].

Benvenist, E. (1974). General linguistics. In Yu.S. Stepanov (Ed.). Moscow : Progress [in Russian].

Beh, I.D. (2003). Vihovannya osobistosti [Education of personality] (Vols. 2). Kyiv : Libid [in Ukrainian].

Borbotko, V.G. (2011). Principy formirovaniya diskursa: Ot psiholingvistiki $k$ lingvosinergetike [Principles of discourse formation. From psycholinguistics to lingo-synergetics]. Moscow : Librokom [in Russian].

Derrida, Zh. (2000). O grammatologii [About grammatology]. Moscow : Ad Marginem [in Russian].

Dejk, van T.A., \& Gerasimova, V.I. (Eds). (1989). Yazyk. Poznanie. Kommunikaciya [Language. Cognition. Communication]. (V.V. Petrova, Y.N. Karaulova, Trans). Moscow : Progress [in Russian].

Grajs, G.P. (1985). Logika i rechevoe obshchenie [Logic and speech communication]. Novoe $v$ zarubezhnoj lingvistike - New in foreign linguistics, XVI. Moscov : Progres [in Russian].

Grejmas, A.Zh., \& Kurte, Zh. (1983). Semiotika [Semiotics]. Obiasnitelnyj slovar teorii iazyka - Explanatory dictionary of the theory of language (pp. 483-550). Moscow : Raduga [in Russian].

Zasiekina, L.V. (2008). Tendencii rozvitku vitchiznyanoï psiholingvistiki: metodologichnij oglyad problem ta okreslennya shlyahiv îh virishennya [Trends in the development of domestic psycholinguistics: a methodological review of the problems and the outline ways to solve them]. Psiholingvistika Psycholinguistics, 1. http://nbuv.gov.ua/UJRN/psling_2008_1_2 [in Ukrainian].

Issers, O.S. (2003). Kommunikativnyye strategii i taktiki russkoy rechi [Communicative strategies and tactics of the Russian speech]. Moscow : Editorial URSS [in Russian].

Kalmykov, G.V. (2012). Tendenciï rozvitku psihologichnoï teoriï diyalnosti yak svitoglyadnoï poziciï diyalnisnoï psiholingvistiki [Trends in the development of psychological theory of the activity as a philosophical position of the active psycholinguistics]. Psiholingvistika - Psycholinguistics, 10, 41-49 [in Ukrainian].

Kalmykov, G.V. (2018). Psihologo-profesijnij diskurs yak virazhennya intencionalnoï spryamovanosti subekta movlennya na adresata [Psychological-professional discourse as an expression of the intentional orientation of the subject of speech to the addressee]. Psiholingvistika - Psycholinguistics, 23(1), 73-98. doi: 10.5281/zenodo.1212362 [in Ukrainian].

Kalmykova, L.O. (2016). Formuvannya u ditej starshogo doshkilnogo viku movlennevö̈ diyalnosti : diagnostiko-rozvivalnij kompleks [Speech activity formation in children of the senior preschool age: diagnostic-developmental complex]. Kyiv : Vidavnichij dim «Slovo» [in Ukrainian].

Kononko, O.L. (Eds.). (2003). Komentar do Bazovogo komponenta doshkilnoï osviti $v$ Ukraïni [Commentary on the basic component of preschool education in Ukraine]. Kyiv: Red. zhurn. «Doshkilne vihovannya» [in Ukrainian].

Karasik, V.I. (2000). O tipah diskursa. Yazykovaya lichnost: institucionalnyj $i$ personalnyj diskurs [About the types of discourse. Language personality: institutional and personal discourse]. Volgograd : Peremena [in Ukrainian]. 
Psychological Features of Verbal Communication of Employees...

Korolov, I.R. (2012). Ponyattya diskursu v suchasnomu movoznavstvi: viznachennya, struktura, tipologiya [The concept of discourse in modern linguistics: definition, structure, typology]. Lingvistika - Linguistics, 6, 285-305 [in Ukrainian].

Krasnyh, V.V. (2012). Osnovy psiholingvistiki [Basics of Psycholinguistics]. Moscow : Gnosis [in Russian].

Kubryakova, E.S. (2000). O ponyatiyah diskursa i diskursivnogo analiza v sovremennoj lingvistike [On the concepts of discourse and discursive analysis in modern linguistics]. Diskurs, rech, rechevaya deyatelnost : funkcionalnye $i$ strukturnye aspekty - Discourse, speech, speech activity: functional and structural aspects (pp. 7-25). Moscow [in Russian].

Lucenko, I.O. (2009). Teoretichni ta metodichni zasadi rozvitku komunikativnomovlennevoï sferi ditini vid narodzhennya do 6 rokiv [Theoretical and methodical principles of the development of communicative-speech sphere of the child from the birth to 6 years]. Kyiv : Vid-vo NPU imeni M.P. Dragomanova [in Ukrainian].

Lucenko, I.O. (2018). Ditinocentrizm yak metodologichnij koncept vihovannya i rozvitku ditej doshkilnogo viku $\mathrm{z}$ rodin uchasnikiv ATO i vnutrishno peremishchenih osib [Child-centeredness as a methodological concept of upbringing and development of preschool children from the families of ATO participants and internally displaced persons]. Post-travmatichnij stresovij rozlad: dorosli, diti ta rodini v situaciï vijni - Post-traumatic stress disorder: adults, children and families in a war situation. (Vols. 3). Warsaw-Kyiv Pan-Gnosis [in Ukrainian].

Milevskaya, T.V. (2002). O ponyatii «diskurs» v rusle kommunikativnogo podhoda. Proceedings from KTPRSK'02: Mezhdunarodna nauchno-praktichna konferenciia «Kommunikaciya: teoriya $i$ praktika $v$ razlichnyh socialnyh kontekstah «Kommunikaciya - 2002» - International scientific-practical conference "Communication: theory and practice in various social contexts» «Communication-2002» («Communication Across Differences»). (Part 1), (pp. 188-190). Pyatigorsk : PSLU [in Russian].

Myasishchev, V.N. (1960). Osnovnye problemy i sovremennoe sostoyanie psihologii otnoshenij cheloveka [The main problems and the current state of psychology of human relations]. Psihologicheskie nauki $v$ SSSR - Psychological sciences in the USSR] (Vols 2). Moscow [in Russian].

Perevalova, D.A. (2013). Pedagogicheskij diskurs: diskurs doshkolnogo obrazovaniya [Pedagogical discourse: discourse of a preschool education]. Vestnik Tomskogo gosudarstvennogo universiteta - Bulletin of Tomsk State University, 368, 23-26 [in Russian].

Semenec, O.O. (2014). Diskursivni praktiki socialnih komunikacij: tvorchist subekta movlennya ta mekhanizmi samoorganizaciï [Discursive practices in social communication: creativity of the subject of speech and mechanisms of selforganization]. Kyiv : BDU [in Ukrainian].

Serazhim, K. (2002). Diskurs yak sociolingvalne yavishche: metodologiya, arhitektonika, variativnist [Discourse as a sociolinguistic phenomenon: methodology, architectonics, variability]. Kyiv [in Ukrainian].

Serio, P. (1999). Kak chitayut teksty vo Francii. Vstupitelnaya statya [How the texts are read in France. Introductory article]. Kvadratura smysla: Francuzskaya shkola analiza diskursa - Quadrature of meaning: French school of discourse analysis (pp. 12-53). Moscow : OAO IG «Progress» [in Russian]. 
Психолінгвістичні особливості вербальної комунікації працівників...

Selivanova, E.A. (2004). Osnovy lingvisticheskoj teorii teksta i kommunikacii [Basics of the linguistic theory of text and communication]. Kyiv : Brama [in Ukrainian].

Sternin, I.A. (2001). Vvedenie v rechevoe vozdejstvie [Introduction to speech exposure]. Voronezh : Polygraph [in Russian].

Habermas, Y., \& Sitnichenko, L.A. (1996). Komunikativna diya i diskurs - dvi formi povsyakdennoï komunikaciï [Communicative action and discourse - the two forms of everyday communication]. Pershodzherela komunikativnoï filosofii Primary sources of communicative philosophy (pp. 84-90). Kyiv : Lybid [in Ukrainian].

Sheigal, E.I. (2000). Semiotika politicheskogo diskursa [Semiotics of political discourse]. Moscow : Volgograd : Peremena [in Russian].

Kristeva, J. (1981). Le language, cet inconnu. Paris : Ed. du Seuil.

Street, R.L., \& Cappella, J.N. (1989). Social and linguistic factor influencing adaptation in children's speech. Journal of Psycholinguistic Research, 18(5), 497-519. doi: 10.1007/BF01067313

Jose, Paul E. (1988). Sequentiality of Speech Acts in Conversational Structure. Journal of Psycholinguistic Research, 17(1), 65-88. doi: 10.1007/BF01067181

Filippova, E., \& Astington, J.W. (2010). Children's Understanding of Social-Cognitive and Social-Communicative Aspects of Discourse Irony. Child Development, 81(3), 913-928. URL : https://www.jstor.org/stable/40599142

\section{АНОТАЦІЯ}

Стаття присвячена проблемі вербальної комунікації вихователів з дітьми дошкільного віку з родин учасників АTO і внутрішньо переміщених осіб. Представлено результати теоретичного аналізу проблеми вивчення дискурсу як психолінгвістичної категорії, який в контексті професійно-мовленнєвої діяльності розглядається як ії вербалізована, зовнішньомовленнєва фраза. Обгрунтовується інтерес психолінгвістики до вивчення особливостей дискурсу освітньої галузі - педагогічного дискурсу, оскільки останній спрямований на реалізацію широкого спектру функцій (виховна, навчальна, комунікативна, організаційна, психологічна (психотерапевтична), в основі яких лежить здійснення педагогом адресантом мовленнєвого впливу на його адресатів (вихованців). Водночас дискурс висвітлюється як діалогічний процес й розкривається двобічний характер впливу комунікантів одне на одного. Урахування педагогом - суб'єктом мовлення індивідуальних особливостей розвитку дитини-адресата, ії психічного стану розглядається як обов'язкова умова забезпечення інтенціональної спрямованості дискурсу. Акцентується важливість реалізації вихователем ЗДО психологічної (психотерапевтичної) функції, що підтверджується потребами практики виховання i розвитку, вербальної комунікації з дітьми з родин учасників АТО $і$ внутрішньо перемішених осіб. Визначено та схарактеризовано типи дискурсів, спроможних надати емоційну підтримку дітям цих категорій у формі дискурсів-позитивні 
Psychological Features of Verbal Communication of Employees...

парціальні оцінки, а саме: дискурс-згода, дискурс-підбадьорювання, дискурс-схвалення, дискурс-випереджальна позитивна оцінка, а також різновиди дискурсів-запитань. Зроблено висновок про те, що різноманітні дискурси, у процесі яких здійснюється мовленнєвий вплив на дитину, ї̈ психічний стан, почуття, поведінку можна розглядати як спеціалізовану дискурсивну практику - психолінгвістичний феномен, основою якого є мовленнєва діяльність ії учасників: вихователів зДО $і$ дітей дошкільного віку.

Ключові слова: дискурс, діалогічний дискурс, дискурсивна практика, мовленнєвий вплив, інтенціональна спрямованість, адресант, адресат.

\section{Луценко Ирина. Психолингвистические особенности вербальной коммуникации работников учреждений дошкольного образования с детьми из семей участников антитеррористических операций и внутренне перемещенных лиц}

\section{АННОТАЦИЯ}

Статья посвящена проблеме вербальной коммуникации воспитателей с детьми дошкольного возраста из семей участников АТО и внутренне перемещенных лиц. Представлено результаты теоретического анализа проблемы изучения дискурса как психолингвистической категории. В контексте профрессионально-речевой деятельности дискурс рассматривается как ее вербализированная внешнеречевая фаза. Обосновывается интерес психолингвистики к изучению дискурса образовательной сфреры - педагогического дискурса, поскольку он направлен на реализацию широкого спектра функций (воспитательная, обучающая, коммуникативная, организационная, психологчческая (психотерапевтическая), в основе которых лежит осуществление педагогом-адресантом речевого воздействия на его адресатов (воспитанников). В то же время дискурс рассматривается как диалогический процесс и раскрывается как двухсторонний процесс воздействия коммуникантов друг на друга. учет педагогом субъектом речи индивидуальных особенностей развития ребенкаадресата, его психического состояния рассматривается как обязательное условие обеспечения интенциональной направленности дискурса. Акцентируется необходимость реализации воспитателем психологической (психотерапевтической) функции, что подтверждается потребностью практики воспитания и развития, вербализированной коммуникации с детьми из семей участников АТО и внутренне перемещенных лиц. Определены и охарактеризированы типы дискурсов, направленные на оказание эмоциональной поддержки детям этих категорий в форме дискурсов-положительные парциальные оценки, а 
Психолінгвістичні особливості вербальної комунікації працівників...

именно: дискурс-согласие, дискурс-подбадривание, дискурс-одобрение, дискурс-опережающая положительная оценка, а также разновидности дискурсов-вопросов. Сделан вывод о том, что разнообразные дискурсы, в прочессе которых осуществляется речевое воздействие на ребенка, его психическое состояние, чувства, поведение можно рассматривать как специализированную дискурсионную практику - психолингвитический феномен, основой которого является речевая деятельность ее участников: воспитателей ДОУ и детей дошкольного возраста.

Ключевые слова: дискурс, диалогический дискурс, дискурсионная практика, речевое воздействие, интенциональная направленность, адресант, адресат. 